\title{
ATOPIA, FACTOR DE RISC ÎN APARIȚIA OTITEI SEROASE LA COPIL
}

\author{
Ileana Ioniuc, Aurica Rugină, Alina Murgu, Irina Criscov, Alice Azoicăi, \\ Paula Popovici, Bogdan Stana, Monica Alexoae \\ Clinica II Pediatrie, Universitatea de Medicină şi Farmacie ,, Gr. T. Popa “, Iaşi
}

\begin{abstract}
REZUMAT
Otita medie seroasă cronică, cauză majoră a hipoacuziei în perioada copilăriei, este frecvent asociată cu sensibilizarea alergică. Prevalența în continuă creştere a atopiei la această vârstă implică o abordare multidisciplinară a copiilor cu adenoidite, otite recurente şi disfuncții tubare, în vederea unui management patogenic complex.

Obiectivul studiului a constat în determinarea asocierii otitelor medii cu bolile alergice, şi implicațiile acestei asocieri în tratamentul şi evoluția pacienților.

Material şi metodă. S-a realizat un studiu retrospectiv care a inclus 92 de copii, cu vârste cuprinse între 6 luni şi 6 ani internați în Clinica II Pediatrie, Spitalul Clinic de Copii „Sf. Maria“, laşi, cu diagnosticul de otită medie, pe o perioadă de 1 an (ianuarie 2015 - ianuarie 2016).

Rezultate. Majoritatea cazurilor au fost otite supurate (61 de pacienți), 31 de cazuri au fost otite seroase, dintre care 23 au fost recurente. Asocierea cu bolile alergice a fost mai frecventă la copiii cu otită seroasă (26/31 cazuri). 4 pacienți cu otită supurată au prezentat reacții adverse la antibiotice, cu implicații majore în evoluția cazurilor. Asocierea cu refluxul gastroesofagian a fost relativ asemănătoare între cele 2 loturi (11/61 de cazuri şi respectiv 10/31 de cazuri), la 10 pacienți atopici, obiectivându-se alergia la proteinele laptelui de vacă.

În concluzie, copiii cu otite medii, în special cei cu otite medii seroase recurente ar trebui investigați pentru determinarea coexistenței atopiei şi a refluxului gastroesofagian, eventual cu dozarea markerilor de inflamație alergică sau a pepsinei în exsudatul otic, în vederea unui management terapeutic țintit.
\end{abstract}

Cuvinte cheie: otită seroasă, alergie, copii

\section{INTRODUCERE}

Otita medie seroasă cronică reprezintă cea mai frecventă cauză de hipoacuzie în perioada copilăriei, fiind frecvent asociată cu bolile alergice. Incidența crescută a atopiei la vârsta pediatrică implică o abordare multidisciplinară a copiilor cu adenoidite, disfuncții tubare şi otite medii în vederea unui tratament patogenic complex.

\section{OBIECTIVUL STUDIULUI}

Obiectivarea asocierii otitelor medii cu bolile alergice şi implicațiile acestei asocieri în tratamentul şi evoluţia pacienților de vârstă pediatrică.

\section{MATERIAL ŞI METODĂ}

S-a realizat un studiu retrospectiv care a cuprins 92 de copii (6 luni - 6 ani), spitalizați în Clinica II Pediatrie pe o perioadă de 1 an (ianuarie 2015 - ianuarie 2016) cu diagnosticul de otită medie acută.
Protocolul de studiu a cuprins: datele de anamneză privind recurența episoadelor de otită şi factorii de risc personali şi familiali atopici sau non-atopici, dificultățile terapeutice, investigații privind etiologia infecțioasă, alergică, malformativă etc. şi asocierea cu bolile alergice. Determinarea concentraţiei in vitro a IgE serice totale s-a efectuat printr-o reacție de aglutinare antigen-anticorp utilizând un sistem RANDOX (Randox Laboratories Limited, United Kingdom), iar determinarea IgE specifice Panel pediatric s-a realizat cu sistemul EUROLINE (Euroimmun Mediziniche Labordiagnostika GmbH, Lubeck, Germany) care oferă o analiză semicantitativă pentru anticorpii umani de tip IgE la aeroalergeni şi alergeni alimentari.

\section{REZULTATE}

Lotul studiat a fost împărțit în 2 subloturi: sublotul 1 - copii cu diagnosticul de otită supurată (+/timpan închis) - 61 de cazuri şi sub lotul 2 - copii diagnosticați de otită medie seroasă -31 de cazuri. 
Distribuția pe mediu de proveniență, sex şi vârstă nu a fost diferită semnificativ între cele 2 subloturi.

Asocierea cu atopia s-a evidențiat mai mult la copiii din sublotul 2, pacienți cu otită seroasă, (26/31 de cazuri) față de lotul 1 (15/61 de cazuri) (Fig. 1) şi la pacienții cu episoade recurente (Fig. 2).

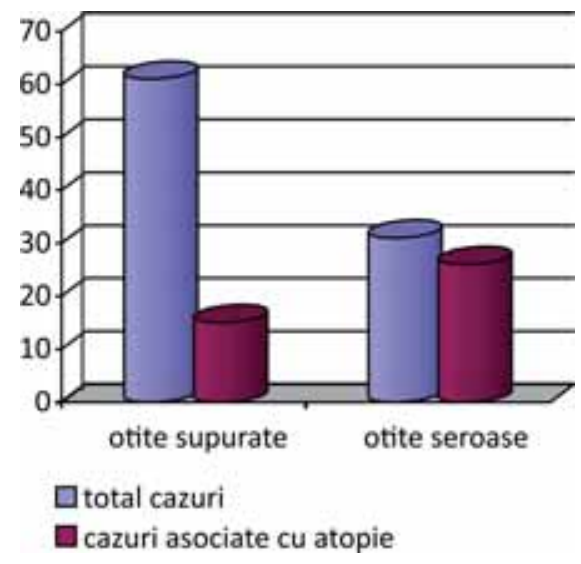

FIGURA 1. Distribuția lotului în funcție de tipul de otită şi asocierea atopiei

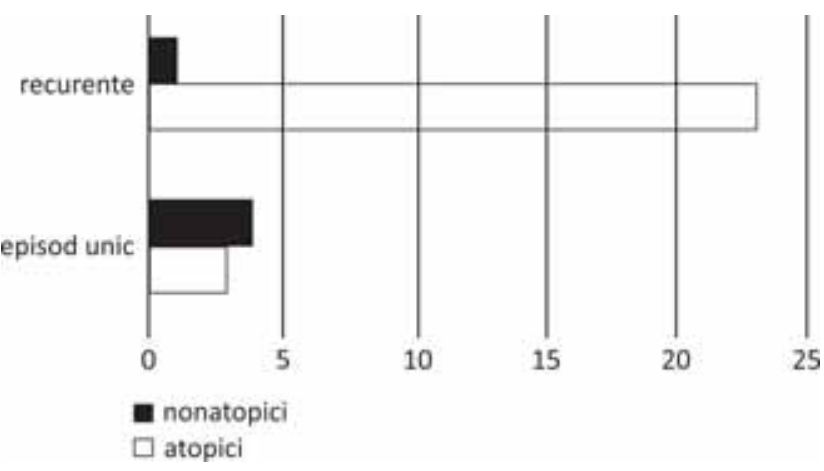

FIGURA 2. Distribuția lotului în funcție de numărul de episoade de otită şi asocierea atopiei

În ceea ce priveşte profilul sensibilizării alergice, s-a observat o frecvență relativ mai crescută a alergiei alimentare, în special la proteinele laptelui de vacă (57\%), urmat de alergia la praful din casă (Fig. 3).

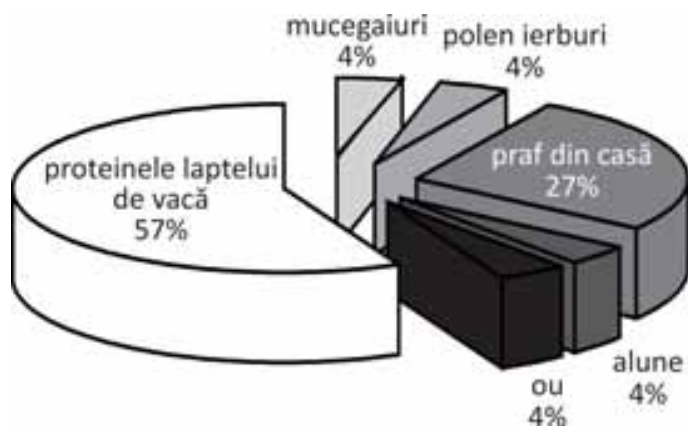

FIGURA 3. Profilul sensibilizărilor alergice în lotul studiat

În cazurile cu alergie la proteinele laptelui de vacă (15 cazuri), s-a evidențiat la majoritatea coexistența refluxului gastroesofagian - 10/15 cazuri.
Cercetarea asocierii cu bolile alergice a obiectivat cel mai frecvent asocierea cu rinita şi rinoadenoidita (54\%), în combinație, uneori, cu astmul bronşic. (Fig. 4)
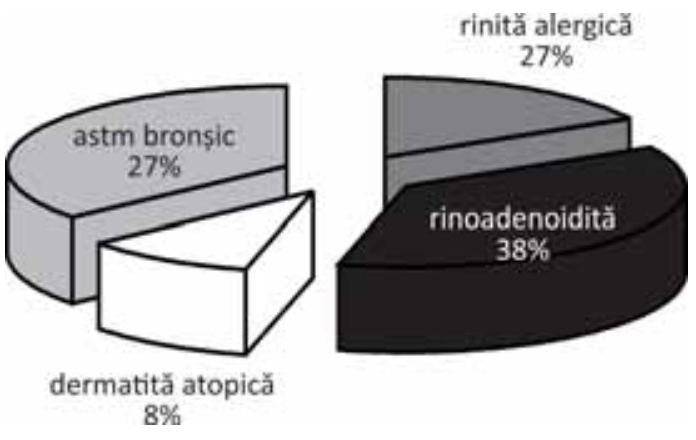

FIGURA 4. Asocierea cu bolile atopice

Spectrul etiologic al otitelor supurate a fost reprezentat de S. pneumoniae, Staphilococcus aureus, Moraxella catarhallis şi, mai rar, Haemophilus inluenzae, 4 pacienți prezentând reacții alergice la antibioticele prescrise (cefalosporine de generația II), cu implicații majore în managementul ulterior al cazurilor.

\section{DISCUȚII}

Relația privind hipersensibilitatea IgE mediată şi otita medie seroasă recurentă a fost demonstrată de numeroase studii. Țesutul adenoidian la copiii nonalergici nu conține sau conține foarte puține celule IgE+, în contrast cu țesutul atopicilor, unde, în special în zona extrafoliculară, se observă un număr extrem de mare de mastocite sau macrofage $\operatorname{IgE}+$. (1) Endoscopia nazală cu biopsie ar juca un rol major în confirmarea diagnosticului şi a asocierii otitei seroase recurente cu atopia (2). Evidențierea terenului atopic în lotul studiat s-a efectuat prin dozarea $\operatorname{IgE}$ serice totale, majoritatea copiilor cu otită seroasă alergică asociind rinită sau rinoadenoidită.

Evaluarea rolului alergiei în apariţia otitei medii seroase s-a realizat mai mult în ceea ce priveşte alergia alimentară, rezultatele fiind controversate. (3) Un studiu de cohortă realizat pe 262 de copii remarcă existența unei corelații semnificative statistic între rinita alergică şi apariţia otitei seroase, fără a se corela semnificativ cu sensibilizarea la polen sau praf. (4) În lotul studiat, majoritatea cazurilor au asociat alergie alimentară de tip alergie la proteinele laptelui de vacă, urmată de alergia la praful din casă.

Prevalența bolii de reflux gastroesofagian la copiii cu otită medie seroasă sau recurentă poate fi mai mare decât prevalența generală în populația studiată (5). În lotul de față se remarcă o asociere 
semnificativă, atât pentru otitele supurate, cât şi pentru cele seroase, mai ales la cei care asociază şi alergie la proteinele laptelui de vacă, asociere frecvent discutată în studiile de specialitate. Testele imunologice şi monitorizarea prin ph metrie esofagiană pot fi utile dacă se suspicionează o asociere între refluxului gastroesofagian şi alergie (6), deşi singurul criteriu cert de diagnostic este dieta de eliminare şi testele de provocare standardizate (7). Prezența pepsinei sau a pepsinogenului în urechea medie la vârstă mică ar putea fi determinate şi de refluxul fiziologic al sugarului, relația de cauzalitate dintre entităţile patologice nefiind încă clar elucidată (8).

Apariţia otitei medii seroase la copiii alergici nu are la bază doar obstrucția şi inflamația trompei lui Eustachio, ci în principal inflamația alergică a epiteliului respirator ce include mucoasa urechii medii. Asocierea terapiei cu antihistaminice şi corticosteroizi intranazali, la terapia standard a otitei medii acute, nu este susținută în totalitate de studi- ile de specialitate, fiind necesară evidențierea asocierii acestor două entități. $(4,11)$ În lotul studiat, după evidențierea prin markeri imunologici sau suspcionarea anamnestică a coexistenței atopiei s-a inițiat terapie specifică şi măsuri dietetice cu evoluție favorabilă pe termen lung, în principal în otitele seroase recurente.

\section{CONCLUZIE}

Copiii cu otite medii, în special cei cu otite medii seroase ar trebui investigați pentru determinarea asocierii atopiei, tratamentul acestora fiind multidisciplinar - medic specialist ORL, alergolog şi pediatru. În cazul obiectivării alergiei la proteinele laptelui de vacă, la aceşti pacienți trebuie urmărită şi eventuala coexistență a refluxului gastroesofagian, eventual cu dozarea pepsinei în exsudatul otic, în vederea unui management terapeutic țintit. 